Jurnal Olahraga \& Kesehatan Indonesia

Volume 1 Nomor 1 (2020)

E-ISSN: 2747-061X

available online at https://jurnal.stokbinaguna.ac.id/index.php/jok

\title{
EFEKTIFITAS MODEL PEMBELAJARAN BERBASIS PERMAINAN UNTUK PENGEMBANGAN KEBUGARAN JASMANI
}

\author{
Hezron Alhim Dos Santos ${ }^{1}$ *, Adnan Hudain ${ }^{2}$ \\ ${ }^{12}$ Universitas Negeri Makassar, Sulawesi Selatan, Indonesia, 90222 \\ *Coressponding Author: hezronsantos@unm.ac.id
}

\section{Keterangan}

Rekam Jejak:

Received, Oktober 2020

Revised, November 2020

Accepted, Desember 2020

Kata Kunci:

Model Pembelajaran,

Permainan, Kebugaran Jasmani
Penelitian ini menggunakan model penelitian dan pengembangan (Research and Development) Oleh karena itu, yang menjadi populasi ini adalah siswa-siswi Sekolah Dasar yang terdapat di Kabupaten Bone Sulawesi Selatan. Pengambilan sampel penelitian ini menggunakan teknik simple random sampling. Pengujian terbatas dilakukan di 3 sekolah dengan 6 sampai 12 subjek. Selanjutnya untuk diuji coba lapangan utama (main field testing) dilakukan pada 5 sampai dengan 15 sekolah dengan menggunakan 30 sampai dengan 100 sampel. Pengembangan model yang dilakukan dalam penelitian ini secara umum melalui dua tahap pengujian yaitu pengujian internal dan pengujian eksternal. Setelah melakukan pengujian internal yang diwujudkan dengan validasi ahli melalui wawancara maka produk yang akan dikembangkan dapat disusun. Model Pembelajaran berbasis Permainan mengembangkan prinsip permainan dengan merangsang keinginan melakukan aktivitas fisik yang sistematis dan terarah dan senang untuk peserta didik. Permainan Jam Kebugaran perlu melibatkan seluruh siswa dalam setiap perannya agar semua siswa dapat bergerak aktif dalam permainan ini dan Permaian Bola Berantai menggunakan bola sebanyak 10 agar setiap peserta didik dapat melakukan gerakan latihan otot perut dengan maksimal. 


\section{PENDAHULUAN}

Penjasorkes merupakan salah satu pendidikan karakter berbasis aktivitas jasmani yang mengharapkan terjadinya perkembangan dari psikomotor, kognitif, afektif pada peserta didik. Globalisasi memang dipandang membawa banyak manfaat dalam bidang penjasorkes akan tetapi seiring perkembangan sistem pembelajaran yang kompleks tersebut terdapat efek negatif. Penggunaan telpon pintar bagi peserta didik berimbas pada kurangnya aktifitas fisik karena waktunya sebagian besar digunakan untuk memantau layar monitor telpon pintar yang mereka miliki. Permainan yang dahulu dimainkan dengan berbagai gerakan fisik kini menjelma menjadi perminan digital yang bisa dimainkan dalam waktu yang lama dalam posisi duduk atau statis. Kekurangan aktivitas gerak seperti ini dapat memicu munculnya berbagai penyakit yang tidak menular terlebih lagi dikarenakan konsumsi bahan makanan yang mengandung banyak glukosa dan lemak.

Berdasarkan buku Pedoman Gizi Seimbang yang dikeluarkan oleh Kementrian kesehatan dipaparkan sebagai berikut, Sebagian besar PTM terkait-gizi di atas berasosiasi dengan kelebihan berat badan dan kegemukan yang disebabkan oleh kelebihan gizi. Data pemeriksaan kesehatan memperlihatkan kecenderungan prevalensi obes (IMT > 25) semua kelompok usia. Anak balita $12,2 \%, 14 \%$, dan $11,9 \%$; usia 6-19 tahun naik dari 5,2\% menjadi 5,9\%; orang dewasa dan usia lanjut naik dari 21,3\% menjadi 22,8\%; dan laki-laki obesitas $19,7 \%$ dan perempuan obesitas 32,9\%. Kelebihan gizi ini timbul akibat kelebihan asupan makanan dan minuman kaya energi, kaya lemak jenuh, gula dan garam tambahan, namun kekurangan asupan pangan bergizi seperti sayuran, bua-buahan dan sereal utuh, serta kurang melakukan aktivitas fisik. Hal ini menunjukkan bahwa penyakit tidak menular seperti obesitas yang disebabkan oleh kelebihan gizi dan kurangnya aktifitas fisik juga mengancam peserta didik usia 6-19 tahun.

Terdapat keistimewaan sifat yang dimiliki oleh anak-anak pada masa pertumbuhan dan perkembangan tubuhnya yaitu keinginan untuk selalu bermain walaupun mereka merasa kelelahan. Bermain bagi anak-anak dalam hal inidapat memberikan informasi, memberikan kesenangan dan mengembangkan imajinasi pada anak. Para pendidik dapat memanfaatkan keistimewaan sifat dari peserta didik ini untuk mengembangkan berbagai model latihan yang menyenangkan namun esensinya bertujuan untuk membentuk peserta didik menjadi pribadi yang sehat dan bugar. Berdasar dari pertimbangan tersebut maka penulis tertarik untuk melakukan penelitian yang berfokus pada Model Pembelajaran Kebugaran Jasmani Berbasis Permainan untuk Mengembangkan Kebugaran Jasmani Siswa Sekolah Dasar.

\section{METODE}

Penelitian ini menggunakan model penelitian dan pengembangan (Research and Development) Oleh karena itu, yang menjadi populasi ini adalah siswa-siswi Sekolah Dasar yang terdapat di Kabupaten Bone Sulawesi Selatan. Pengambilan sampel penelitian ini menggunakan teknik simple random sampling. Pengujian terbatas dilakukan di 3 sekolah dengan 6 sampai 12 subjek. Selanjutnya untuk diuji coba lapangan utama (main field testing) dilakukan pada 5 sampai dengan 15 sekolah dengan menggunakan 30 sampai dengan 100 sampel.

\section{HASIL \& PEMBAHASAN}

Pengembangan model yang dilakukan dalam penelitian ini secara umum melalui dua tahap pengujian yaitu pengujian internal dan pengujian eksternal. Setelah melakukan pengujian internal yang diwujudkan dengan validasi ahli melalui wawancara maka produk yang akan dikembangkan dapat disusun. Model Pembelajaran Kebugaran berbasis Permainan mengembangkan prinsip permainan dengan merangsang keinginan melakukan aktivitas fisik yang sistematis dan terarah dan senang untuk peserta didik. Model Pembelajaran Kebugaran 
Jasmani berbasis permainan untuk meningkatkan kebugaran jasmani siswa Sekolah Dasar pada tahap uji validasi ahli terdapat beberapa masukan dan saran untuk revisi atau perbaikan model. Adapun beberapa masukan dan saran ahli dan Pembina yaitu:

- Aktivitas Permainan melibatkan seluruh peserta didik agar tidak ada yang diam dan menjadi penonton sehingga peserta didik aktif dalam ikut serta permainan tersebut.

- Alokasi Waktu yang disediakan untuk melakukan aktivitas permainan tersebut tetap memperhatikan waktu pembelajaran yang disediakan.

- Pergerakan anak-anak pada permainan Jam Kebugaran dengan memanfaatkan kekuatan otot lengan sebaiknya memperhatikan asas keamanan dan menghindari terjadinya cedera.

- Permainan Menaklukkan Benteng sebaiknya ditiadakan saja hal ini dikarenakan permainan tersebut kurang mengandung unsur permainan sehingga masih cenderung monoton.

Revisi terhadap usulan model oleh para ahli selanjutnya menghasilkan model yang telah dikembangkan namun perlu ada uji lapangan terbatas terhadap model ini untuk melihat kelebihan dan kekurangan model sehingga dapat dilakukan revisi.

Hasil Uji Lapangan Awal/Terbatas

Uji lapangan awal ini diikuti oleh peserta didik sebanyak 10 orang yang berasal dari SD Negeri Inpres 12/79 Biru. Maksud dan tujuan dari uji coba produk pada kelompok kecil ini untuk mengetahui dan mengidentifikasi berbagai permasalahan seperti kelemahan atau kekurangan dan keefektifan produk pada waktu digukan oleh siswa. Pengumpulan data uji coba lapangan awal ini dilakukan dengan menggunakan kuesioner untuk mengetahui tanggapan awal oleh peserta didik terhadap model Pembelajaran Kebugaran Jasmani Berbasis Permaian . Data yang telah dikumpulkan selanjutnya menjadi bahan untuk merevisi produk sebelum digunakan dalam uji coba lapangan utama. Data pengujian lapangan awal/terbatas yang diperoleh dari beberapa peserta didik memperlihatkan hasil sebagai berikut:

Tabel 1. Hasil Uji Lapangan Awal/Terbatas

\begin{tabular}{|c|c|c|c|c|}
\hline No & Pertanyaan & Skor & $\%$ & Kategori \\
\hline 1 & $\begin{array}{l}\text { Apakah anda dapat melakukan aktifitas fisik } \\
\text { dengan mudah? }\end{array}$ & 7 & 70 & Baik \\
\hline 2 & $\begin{array}{c}\text { Apakah anda menyukai aktifitas permainan } \\
\text { kebugaran jasmani? }\end{array}$ & 8 & 80 & Baik \\
\hline 3 & $\begin{array}{c}\text { Apakah anda menyukai aktifitas kebugaran } \\
\text { Push Up? }\end{array}$ & 3 & 30 & Tidak Baik \\
\hline 4 & $\begin{array}{c}\text { Apakah anda menyukai aktifitas kebugaran } \\
\text { Sit Up? }\end{array}$ & 5 & 50 & Kurang Baik \\
\hline 5 & Apakah anda menyukai permainan? & 9 & 90 & Sangat Baik \\
\hline 6 & $\begin{array}{l}\text { Apakah anda merasa senang dengan } \\
\text { kegiatan permainan Jam Kebugaran? }\end{array}$ & 8 & 80 & Baik \\
\hline 7 & $\begin{array}{c}\text { Apakah anda dapat bekerjasama dengan baik } \\
\text { dengan teman dalam permainan ini? }\end{array}$ & 8 & 80 & Baik \\
\hline 8 & $\begin{array}{c}\text { Apakah anda menyukai bermain Bola } \\
\text { Berantai? }\end{array}$ & 9 & 90 & Sangat Baik \\
\hline \multirow[t]{2}{*}{9} & $\begin{array}{c}\text { Apakah anda dapat bersemangat dalam } \\
\text { bermain Bola Berantai? }\end{array}$ & 8 & 80 & Baik \\
\hline & Keterangan & 7,2 & 72,00 & Baik \\
\hline
\end{tabular}

Tabel di atas menujukkan bahwa respon dari peserta didik terhadap produk model Pembelajaran kebugaran Jasmani berbasis Permainan pada uji lapangan awal dapat dikatakan secara umum memperoleh bobot presentase $72,00 \%$. Apabila ditinjau dari aspek-aspek pendapat para peserta didik mengenai produk model Pembelajaran yang diuji cobakan memperoleh gambaran sebagai berikut: 
- Aspek melakukan aktifitas fisik memperoleh persentase sebesar $70 \%$ dan berdasarkan kriteria yang telah ditetapkan maka aspek ini termasuk dalam kriteria „baik”sehingga dapat digunakan.

- Aspek kesukaan melakukan aktifitas permainan kebugaran jasmani memperoleh persentase sebesar $80 \%$ dan berdasarkan kriteria yang telah ditetapkan maka aspek ini termasuk dalam kriteria „baik”sehingga dapat digunakan.

- Aspek menyukai aktifitas push-up memperoleh persentase sebesar $30 \%$ dan berdasarkan kriteria yang telah ditetapkan maka aspek ini termasuk dalam kriteria „tidak baik”sehingga tidak dapat digunakan.

- Aspek menyukai aktifitas sit-up memperoleh persentase sebesar $50 \%$ dan berdasarkan kriteria yang telah ditetapkan maka aspek ini termasuk dalam kriteria „tidak baik”sehingga tidak dapat digunakan.

- Aspek menyukai permainan memperoleh persentase sebesar $90 \%$ dan berdasarkan kriteria yang telah ditetapkan maka aspek ini termasuk dalam kriteria „sangat baik”sehingga dapat digunakan.

- Aspek senang dalam melakukan permainan jam kebugaran jasmani memperoleh persentase sebesar $80 \%$ dan berdasarkan kriteria yang telah ditetapkan maka aspek ini termasuk dalam kriteria „baik”sehingga dapat digunakan.

- Aspek bekerjasama dengan baik dalam melakukan permainan jam kebugaran memperoleh persentase sebesar $70 \%$ dan berdasarkan kriteria yang telah ditetapkan maka aspek ini termasuk dalam kriteria „baik”sehingga dapat digunakan.

- Aspek kesukaan terhadap permainan bola berantai memperoleh persentase sebesar $90 \%$ dan berdasarkan kriteria yang telah ditetapkan maka aspek ini termasuk dalam kriteria ,sangat baik"sehingga dapat digunakan.

- Aspek semangat dalam melakukan permainan bola berantai memperoleh persentase sebesar $80 \%$ dan berdasarkan kriteria yang telah ditetapkan maka aspek ini termasuk dalam kriteria „baik”sehingga dapat digunakan.

Revisi Model

Revisi pertama terhadap model Pembelajaran Kebugaran Jasmani berbasis permainan dilakukan berdasarkan hasil analisis terhadapa uji coba lapangan terbatas dan wawancara para ahli. Berdasarkan wawancara dengan Prof. Dr. H. Andi Ihsan, M.Kes diperoleh informasi bahwa untuk aktivitas fisik yang merujuk kepada kebugaran jasmani yang berbasis permainan sebaiknya diarahkan ke permainan yang membawa kesenangan bagi peserta didik namun tidak menghilangkan esensi dari tujuannya yaitu untuk membugarkan peserta didik. Permaianan tersebut juga perlu mengutamakan perkembangan kecerdasan emosional peserta didik atau rana afektifnya seperti kerjasama, saling menghargai dan disiplin. Pendapat Dr. Irfan, M.Pd. mengenai akttivitas permainan yang dilakukan oleh para siswa sebaiknya memperhatikan asas keamanan hal ini dikarenakan ketika keasikan melakukan gerakan-gerakan permainan peserta didik juga dihindarkan dari cedera. Permaianan Jam Kebugaran dan Bola Berantai sudah baik dan perlu diimplementasikan dalam uji selanjutnya. Pengujian terhadap model pembelajaran berbasis permainan ini diperlukan agar dapat diketahui manfaat permainan tersebut bagi perkembangan kebugaran peserta didik yang ditinjau dari kekutan otot lengan dan kekuatan otot perutnya. Pendekatan Uji selanjutnya dilakukan dalam dua tahap yaitu Uji Lapangan Utama dan Uji Lapangan Operasional.

Hasil Uji Lapangan Utama/Besar

Uji coba lapangan utama dilakukan pada 5 Sekolah Dasar yang terdapat dikabupaten Bone dengan sampel sebanyak 30 orang. Uji coba lapangan utama dilakukan setelah merevisi model sebelumnya yang telah mendapatkan respon dari beberapa peserta didik dalam tahap pengujian lapangan awal. Pada uji lapangan utama ini pengumpulan data menggunakan metode eksperimen, sehingga efektivitas produk (pendidikan) dapat diketahui dengan membandingkan 
nilai sebelum dan setelah penerapan model Pembelajaran Kebugaran Jasmani Berbasis Permainan.

Tabel 2. Hasil Uji Lapangan Utama/Besar

\begin{tabular}{|c|c|c|c|}
\hline Pasangan Sampel & Korelasi & Rata-rata & Signifikan \\
\hline Pre Test Angkat Tubuh & \multirow{2}{*}{0.703} & 16.4 & \multirow{2}{*}{0.000} \\
\hline Pos Test Angkat Tubuh & & 19.03 & \\
\hline Pre Test Baring Duduk & \multirow{2}{*}{0.552} & 12.33 & \multirow{2}{*}{0.002} \\
\hline Pos Test Baring Duduk & & 16.7 & \\
\hline
\end{tabular}

Berdasarkan tabel di atas memperlihatkan bahwa:

- Tes angkat tubuh sebelum perlakuan dan setelah perlakuan berkorelasi sebesar 70,3\% dengan nilai signifikan 0,000. Rata-rata nilai angkat tubuh sebelum perlakuan sebesar 16 detik dan setelah perlakuan sebesar 19 detik. Hal ini berarti terdapat peningkatan sebesar 3 detik.

- Tes baring sebelum perlakuan dan setelah perlakuan berkorelasi sebesar 55,2 \% dengan nilai signifikan 0,002. Rata-rata nilai baring duduk sebelum perlakuan sebesar 12 kali dan setelah perlakuan sebesar 16 kali. Hal ini berarti terdapat peningkatan kecepatan 4 kali.

Model Pembelajaran Kebugaran Jasmani untuk meningkatkan kebugaran siswa sekolah dasar dalam uji lapangan utama memperlihatkan hasil yang baik namun belum maksimal. Masih terdapat beberapa masukan dalam menyempurnakan model ini diantaranya yaitu:

- Permainan Jam Kebugaran perlu melibatkan seluruh siswa dalam setiap perannya agar semua siswa dapat bergerak aktif dalam permainan ini.

- Peraturan yang diberikan kepada siswa dibuat lebih sederhana agar lebih mudah dipahami dan dilaksanakan.

- Permaian Bola Berantai sebaiknya menggunakan Bola sebanyak 10 agar setiap peserta didik dapat melakukan gerakan latihan otot perut dengan maksimal.

Revisi yang dilakukan setelah uji lapangan utama dengan menimbang beberapa masukan diatas kemudian dilanjutkan dengan uji lapangan operasional agar produk yang dikembangkan dapat diimplementasikan dalam dunia pendidikan.

Hasil Uji Lapangan Operasional

Uji lapangan operasional dilakukan pada 10 sekolah dasar yang terdapat di Kabupaten Bone dengan sampel sebanyak 50 orang. Pengujian ini menggunakan metode eksperimen. Efektivitas produk dpat diketahui dengan membandingkan nilai sebelum dan sesudah menggunakan produk yang dalam hal ini adalah model Pembelajaran Kebugaran Jasmani berbasis Permainan. Berdasarkan perlakuan yang diterapkan pada 50 sampel selama 12 kali pertemuan dapat diperlihatkan pada tabel berikut:

Tabel 3. Hasil Uji Lapangan Operasional

\begin{tabular}{cccc}
\hline Pasangan Sampel & Korelasi & Rata-rata & Signifikan \\
Pre Test Angkat Tubuh & 0.829 & 16.32 & 0.00 \\
Pos Test Angkat Tubuh & & 27.36 & \\
Pre Test Baring Duduk & 0.803 & 12.52 & 0.02 \\
Pos Test Baring Duduk & & 21.16 & \\
\hline
\end{tabular}

Berdasarkan tabel di atas memperlihatkan bahwa:

- Tes angkat tubuh sebelum perlakuan dan setelah perlakuan berkorelasi sebesar 82,9\% dengan nilai signifikan 0,000 . Rata-rata nilai angkat tubuh sebelum perlakuan sebesar 16,23 detik dan setelah perlakuan sebesar 27,36 detik. Hal ini berarti terdapat peningkatan sebesar 9,13 detik. 
- Tes baring sebelum perlakuan dan setelah perlakuan berkorelasi sebesar 80,3\% dengan nilai signifikan 0,002. Rata-rata nilai baring duduk sebelum perlakuan sebesar 12 kali dan setelah perlakuan sebesar 21 kali. Hal ini berarti terdapat peningkatan sebanyak 9 kali. Lebih lanjut kemampuan rata-rata peserta didik untuk baring duduk termasuk dalam nilai " 3 " meningkat ke nilai "4".

Esensi dari model pembelajaran kebugaran jasmani berbasis permainan yaitu kesehatan dinamis atau kebugaran peserta didik yang dapat diperoleh melalui latihan kebugaran yang melibatkan kontraksi otot-otot seperti otot lengan maupun otot perut. Pengembangan Model Pembelajaran Kebugaran Jasmani berbasis permainan yang bertujuan meningkatkan kebugaran jasmani merupakan model pengembangan yang tidak menghilangkan muatan latihan kebugaran itu sendiri melainkan lebih menekankan agar peserta didik merasa senang ketika melakukan aktivitas kebugaran jasmani. Pendidikan dan pengajaran yang di tujukan kepada peserta didik bukan hanya sebatas teori akan tetapi lebih kepada praktik.

Pola hidup sehat yang ditanamkan kepada peserta didik dangat dianjurkan sejak usia sekolah dasar. Prosesnya pun tidak instan melainkan bertahap dan berkesinambungan. Aktivitas fisik dalam hal ini permainan yang dilakukan setiap hari sebelum pembelajaran di ruang kelas dimulai bertujuan memicu perkembangan bukan hanya tubuh melainkan juga perkembangan otak peserta didik. Rangsangan terhadap hormon pertumbuhan dapat membuat peserta didik mengalami pertumbuhan dan perkembangan yang baik. Lebih jauh, pelaksanaan kegiatan ini jelas dapat meningkatkan kebugaran jasmani peserta didik. Aktivitas ini kemudian membawa manfaat yang banyak bagi kesehatan peserta didik.

Pemberian beban tertentu terhadap otot lengan merupakan salah satu cara untuk melatih kekuatan otot lengan. Beban yang diberikan terdiri atas 2 jenis yaitu beban internal (tubuh) dan beban eksternal (alat). Permainan Jam Berantai memperlihatkan cara melatih kekuatan otot lengan yang diadopsi dari gerakan push-up yang dapat melatih otot dada dan otot lengan. Peserta didik yang berfungsi menjadi jarum jam akan bergerak dengan memanfaatkan kekuatan otot lengannya dengan menopang berat tubuh mereka sendiri. Gerakan inilah yang akan merangsang bertambahnya unsur kontraktil (aktin dan myosin) didalam otot sehingga menyebabkan bertambahnya kekuatan aktif otot. Perserta didik yang awalnya bermalas-malasan dalam melakukan aktifitas kebugaran jasmani dikarenakan sifat gerakan yang monoton akan berubah menjadi senang dalam melakukan aktifitas permainan jam kebugaran. Kesenangan dan semangat dalam melakukan kegiatan inilah yang akan merangsang keinginan untuk melakukan aktifitas kebugaran jasmani ini secara berkesinambungan sehingga diharapkan tujuan pembelajaran kebugaran jasmani dapat tercapai dengan baik.

Permainan Bola Berantai memanfaatkan prinsip pelatihan pengulangan kontraksi otot. Pengulangan ini diberikan bukan dengan hitungan yang sering dianggap beban bagi peserta didik dalam melakukan latihan sit-up melainkan disesuikan dengan jumlah bola yang mereka mainkan. Setiap anggota kelompok akan melakukan gerakan mengangkat tubuh dan berbaring selama 10 kali jika diberikan bola sebanyak 10 bola juga. Perbedaannya adalah pada saat melakukan permainan ini perasaan semangat dan senang menyebabkan peserta didik tidak akan jenuh dan bosan melainkan ingin seringseing melakukan permainan ini. Secara tidak sadar peserta didik melakukan latihan kebugaran Jasmani untuk melatih otot perutnya. Prinsip pengulangan dalam mengangkat beban (internal) ketika bermain bola berantai akan berdampak kepada peningkatan daya tahan otot peserta didik sehingga berimplikasi kepada keseimbangan tubuh mereka. Otot perut yang semakin sering dilatih akan memberik dampak yang positif terhadap kebugaran peserta didik namun hal tersebut perlu pengawasan dari pendidik agar tidak kelebihan beban latihan yang berdampak pada cedera. 


\section{SIMPULAN}

Pengembangan model yang dilakukan dalam penelitian ini secara umum melalui dua tahap pengujian yaitu pengujian internal dan pengujian eksternal. Setelah melakukan pengujian internal yang diwujudkan dengan validasi ahli melalui wawancara maka produk yang akan dikembangkan dapat disusun. Model Pembelajaran Kebugaran berbasis Permainan mengembangkan prinsip permainan dengan merangsang keinginan melakukan aktivitas fisik yang sistematis dan terarah dan senang untuk peserta didik. Permainan Jam Kebugaran perlu melibatkan seluruh siswa dalam setiap perannya agar semua siswa dapat bergerak aktif dalam permainan ini dan Permaian Bola Berantai menggunakan Bola sebanyak 10 agar setiap peserta didik dapat melakukan gerakan latihan otot perut dengan maksimal.

\section{DAFTAR PUSTAKA}

Andi \& Hasmiyati. (2011). Manajemen Pendidikan Jasmani Olahraga dan Kesehatan. Makassar: Badan Penerbit UNM.

Creswell, John. (2016). Desain (Pendekatan Metode Kualitatif, Kuantitatif, Campuran). Edisi Keempat. Yogyakarta: Penerbit Pustaka Pelajar.

Dawn Penney, Gill Clarke, Mandy Quill, \& Gary Kinchin. (2005). Sport Education in Physical Education. New York: Routledge Taylor and Francis Group.

Griwijoyo, Santosa \& Sidik, Dikdik Zafar. (2012). Ilmu Faal Olahraga. Bandung: PT. Remaja Rosdakarya.

Griwijoyo, Santosa., Ichsan., Harsono., dkk. (2005). Manusia dan Olahraga. Bandung: Penerbit ITB.

Harsuki. (2012). Pengantar Manajemen Olahraga. Jakarta: PT Raja Grafindo Persada.

Husdarta \& Kusmaedi. (2012). Pertumbuhan dan Perkembangan Peserta Didik (Olahraga dan Kesehatan). Bandung: Alfabeta.

Husdarta \& Saputra. (2013). Belajar dan Pembelajaran Pendidikan Jasmani dan Kesehatan. Bandung: Alfabeta.

Husdarta. (2009). Manajemen Pendidikan Jasmani. Bandung: Alfabeta.

Husdarta. (2010). Sejarah dan Filsafat Olahraga. Bandung: Alfabeta.

Ichsan, Nur Halim. (2011). Tes dan Pengukuran Kesegaran Jasmani. Makassar: Badan Penerbit UNM. 